\title{
Introduction: nonprofit sector management and social entrepreneurship: a teacher's toolbox
}

\author{
Karabi C. Bezboruah and Heather L. Carpenter
}

\section{INTRODUCTION TO THE BOOK}

The nonprofit sector refers to the sum of private, voluntary, nonprofit organizations, and associations (Anheier, 2014). The sector comprises ten sub-sectors that encompass over 1.5 million organizations across various industries - hospitals and health services, museums and cultural associations, educational and research institutions, religious and faith-based organizations, among others within the United States (McKeever, 2018). Globally, it is estimated there are over 35000 non-governmental organizations registered with the United Nations (Lewis, 2010).

One salient characteristic of this sector in the United States and around the world is its diversity not only in terms of the number of organizations but also in their organizational missions as well as the types of services they provide. Besides charitable 501c3 nonprofit organizations and foundations (in the United States), other 501c nonprofit organizations (in the United States) include social clubs, labor unions, consumer organizations, grassroots groups, and credit unions among others.

Most nonprofit organizations are entities created for purposes that benefit the public. Profit making from organizational operations is not an objective and neither is profit distribution among organizational stakeholders. Nonprofit organizations in the United States have played an important role in advocating for issues that affect the public by bringing about changes in legislation. They have also been instrumental in implementing public programs supported by the various levels of government (Fyall, 2017; Smith and Lipsky, 1993). In many countries and internationally, non-governmental organizations (NGOs) have provided many needed services and support for countries to operate, such as international aid and development. The values espoused by nonprofit organizations such as public benefit mission, maintenance of goodwill and public 
trust, and adherence to mission to maintain accountability to their stakeholders clearly suggest a special context for the management of such organizations (Jeavons, 1992).

Many nonprofit organizations that started out as voluntary groups incorporated as needed to create formal operating procedures and practices. Over time, nonprofits have created organizational processes that reflect business-like management techniques such as professionalism, commercialization, corporatization, marketization, and entrepreneurial orientation while addressing socio-economic-political pressures (Maier et al., 2016). Although there hasn't been one agreed-upon set of competencies (knowledge, skills, abilities and other characteristics) identified for the managers who run nonprofit organizations, scholars and infrastructure organizations have attempted to understand the various dimensions of management in the context of nonprofit organizations (e.g., Ahmed, 2005; Block, 1998; Burlingame, 2009; Dolan, 2002; Kamaria and Lewis, 2009).

\section{NONPROFIT MANAGEMENT CURRICULUM}

The immense growth in the scope and scale of nonprofit organizations led to a high demand for nonprofit managers (Salamon and Sokolowski, 2005). It also resulted in a significant focus on nonprofit management education at both the graduate and undergraduate levels. In 2000, Mirabella and Wish identified more than 90 graduate-degree programs in the United States with more than three courses in nonprofit management. This number has grown to be about 338 colleges and universities with courses in nonprofit management (Mirabella, 2019).

Similar to the diversity of the nonprofit organizations, nonprofit education programs are diverse in their offerings, and are housed in a variety of academic disciplines across universities. The disciplines include, but are not limited to, Public Administration, Political Science, Public Policy, Arts and Sciences, Business, and Social Work and Leadership. Students studying nonprofit management can pursue degrees at the Bachelor's, Master's and Ph.D. levels (Mirabella and McDonald, 2013). The Bachelor's degrees in Nonprofit Management or similar are offered in person, online, and/or hybrid. There are approximately 50 stand-alone Master's degrees in the USA in Nonprofit Management or Philanthropic Studies (Mirabella, 2019). The other 260+ Master's degrees offer an emphasis or concentration in Nonprofit and Philanthropic studies. There is only one school of Philanthropic Studies in the United States that offers a Ph.D. in Philanthropic Studies; the other approximate $42 \mathrm{Ph}$.D. programs are in other disciplines and provide students an opportunity to study and conduct their dissertations in Nonprofit and Philanthropic studies (Carpenter, 2016). 
Many of the nonprofit academic programs are members of the Nonprofit Academic Centers Council (NACC), a membership organization created in 1991 with the mission to "support academic centers devoted to the study of the nonprofit/nongovernmental sector, philanthropy and voluntary action" (NACC, 2015, p. 4). The NACC hosts a bi-annual conference focused on teaching, curriculum and administration, which created an initial set of curricular guidelines in 2007 for both the undergraduate and graduate study of nonprofit, philanthropy and voluntary action.

Although there have been articles and books focusing on nonprofit organizations and documenting statistics of nonprofit management education, the field lacks guidebooks on teaching nonprofit management education. This book provides strategies and practices for teaching nonprofit management theories and concepts in the context of the undergraduate, graduate, and online classroom environments. The most recent iteration of NACC curricular guidelines (see Table I.1) were used in writing this book (NACC, 2015).

Most nonprofit and philanthropy studies programs provide a course on the overview of nonprofit organizations, and/or the nonprofit and philanthropic sector. However, the philosophy or academic perspectives behind each of these courses are somewhat different based on the academic or practitioner-academic discipline of the professor. As the field of nonprofit management is interdisciplinary, the NACC guidelines provide a centralized list of possible topics for inclusion in nonprofit management curricula.

In order to teach nonprofit management effectively, one must have a broad understanding of the nonprofit sector, philanthropy, voluntary, and various interdisciplinary perspectives that influence the field of nonprofit management. Burlingame (2009) argues that those teaching nonprofit and philanthropic studies need to emphasize the liberal arts. It is common knowledge that the liberal arts include many arts and sciences disciplines, such as history, philosophy, arts, psychology, and the social sciences (e.g., economics, sociology, history, law, etc.). The complexity of running nonprofit organizations requires an understanding of both the liberal arts and professional skills. The NACC curricular guidelines provide inclusion of both the liberal arts and the professional skills needed to manage a nonprofit organization.

Due to the diversity of the nonprofit sector, the authors will use the terms "nonprofit", "philanthropic", "voluntary sector", and "civil society" interchangeably throughout the book. Some scholars view these terms differently; however, the NACC guidelines include these terms. Also, the terms "nonprofit organizations" and "NGOs" may be used interchangeably as well. 
Table I.1 NACC Curricular Guidelines (2015)

\begin{tabular}{|c|c|c|c|}
\hline \multicolumn{2}{|c|}{ Graduate } & \multicolumn{2}{|c|}{ Undergraduate } \\
\hline 1.0 & $\begin{array}{l}\text { Comparative Perspectives on the Nonprofit } \\
\text { Sector, Voluntary Action and Philanthropy }\end{array}$ & 1.0 & $\begin{array}{l}\text { Comparative Perspectives on Civil Society, } \\
\text { Voluntary Action and Philanthropy }\end{array}$ \\
\hline 2.0 & $\begin{array}{l}\text { Scope and Significance of the Nonprofit } \\
\text { Sector, Voluntary Action and Philanthropy }\end{array}$ & 2.0 & $\begin{array}{l}\text { Foundations of Civil Society, Voluntary } \\
\text { Action and Philanthropy }\end{array}$ \\
\hline 3.0 & $\begin{array}{l}\text { History and Theories of the Nonprofit } \\
\text { Sector, Voluntary Action and Philanthropy }\end{array}$ & 3.0 & Ethics and Values \\
\hline 4.0 & Ethics and Values & 4.0 & $\begin{array}{l}\text { Public Policy, Law, Advocacy and Social } \\
\text { Change }\end{array}$ \\
\hline 5.0 & Nonprofit Governance and Leadership & 5.0 & Nonprofit Governance and Leadership \\
\hline 6.0 & Public Policy, Advocacy and Social Change & 6.0 & Community Service and Civic Engagement \\
\hline 7.0 & Nonprofit Law & 7.0 & Leading and Managing Organizations \\
\hline 8.0 & Nonprofit Economics & 8.0 & Nonprofit Finance and Fundraising \\
\hline 9.0 & Nonprofit Finance & 9.0 & Financial Management \\
\hline 10.0 & Fundraising and Resource Development & 10.0 & Managing Staff and Volunteers \\
\hline 11.0 & Financial Management and Accountability & 11.0 & Nonprofit Marketing \\
\hline 12.0 & $\begin{array}{l}\text { Leadership, Management, Innovation and } \\
\text { Entrepreneurship }\end{array}$ & 12.0 & $\begin{array}{l}\text { Assessment, Evaluation and } \\
\text { Decision-Making Methods }\end{array}$ \\
\hline 13.0 & Nonprofit Human Resource Management & 13.0 & Professional and Career Development \\
\hline 14.0 & Nonprofit Marketing and Communications & & \\
\hline 15.0 & $\begin{array}{l}\text { Information Technology, Social Media and } \\
\text { Data Management }\end{array}$ & & \\
\hline 16.0 & $\begin{array}{l}\text { Assessment, Evaluation and } \\
\text { Decision-Making Methods }\end{array}$ & & \\
\hline
\end{tabular}

\section{ORGANIZATION OF THIS BOOK}

This book attempts to create some continuity and discuss and summarize pertinent nonprofit and philanthropic theories and concepts with concrete examples of nonprofit management education courses. Each chapter begins with a discussion of both theories and concepts that relate to each nonprofit management topic(s). Then exercises or simulations and other resources are included to help instructors to apply the theory and concepts to either physical or virtual classrooms. The chapters are formatted according to the NACC graduate curricular guideline topics, but we have given our authors flexibility to offer different resources within their chapters. This book is not meant to be exhaustive in covering every area of nonprofit management but attempts to add to the ongoing development of teaching nonprofit management. 


\section{CHAPTER OVERVIEWS}

In Chapter 1, using NACC guidelines 1.0 and 2.0, we briefly discuss comparative global perspectives of the nonprofit sector and the size of the scope of the nonprofit sector and provide relevant teaching exercises and activities. We also provide general resources for teaching nonprofit management. In Chapter 2, Peter C. Weber discusses teaching the history of nonprofit and philanthropic studies in alignment with NACC Curricular graduate guideline 3.0: History and Theories of the Nonprofit Sector, Voluntary Action and Philanthropy. In Chapter 3, Karabi C. Bezboruah discusses the importance of teaching ethics and accountability in theory and in practice while applying NACC curricular guideline 4.0: Ethics and Values. Lyn P. Corbett and Colton C. Strawser, in Chapter 4, provide an overview of teaching nonprofit governance using NACC curricular guideline 5.0: Nonprofit Governance and Leadership. In Chapter 5, Elizabeth A. Castillo presents three theoretical frameworks, resources, and applications instructors can use to teach leadership in pluralistic contexts applying NACC curricular guideline 12.0: Leadership, Management, Innovation and Entrepreneurship. In Chapter 6, Shelly Arsneault and Shannon K. Vaughan provide a background and context for teaching the relationship between nonprofit organizations and public policy, using the four facets of a Nonprofit-Policy framework and NACC curricular guideline 6.0: Public Policy, Advocacy and Social Change. Darla J. Hamann, in Chapter 7, provides a brief overview of teaching the three areas of United States law that nonprofit executives need to be familiar with in the context of NACC curricular guideline 7.0: Nonprofit Law. In Chapter 8, Alicia Schatteman and Li-Yin Liu summarize the key concepts of nonprofit finance, connecting those to the NACC curricular guidelines 9.0: Nonprofit Finance and 11.0: Financial Management and Accountability. In Chapter 9, Michelle Wooddell focuses on both the practical and theoretical aspects of teaching fund development applying NACC curricular guideline 10.0: Fundraising and Resource Development.

The book expands a bit beyond NACC guideline 10 for Chapter 10, where Elizabeth J. Dale, Genevieve G. Shaker and Heather A. O'Connor discuss how instructors can integrate the study of philanthropy alongside more common nonprofit sector topics, such as fundraising, grantmaking, and leadership, to both inspire and analyze approaches to giving. In Chapter 11, Stuart C. Mendel discusses teaching social enterprise concepts and applications using undergraduate NACC curricular guideline 7.5: social enterprise and other entrepreneurial forms of nonprofit organization and subsection 7.6: the role of social entrepreneurs in nonprofit leadership and management and graduate guideline 12.8: models and new frameworks for both social entrepreneurship and social enterprise. In Chapter 12, Lauren Miltenberger describes teaching 
human resource management using NACC guideline 13.0: Nonprofit Human Resource Management. Heather L. Carpenter, in Chapter 13, uses NACC curricular guideline 14.0: Nonprofit Marketing and Communications in discussing teaching nonprofit marketing. In Chapter 14, Jimmy A. Young focuses on teaching nonprofit educators, managers, and others how to use social media and information communication technologies, or digital media, in a way that promotes an organization by connecting it to a greater community of digital participants by applying NACC curricular guideline 15.0: Information Technology, Social Media and Data Management. Tara Kolar Bryan and Jodi Benenson in Chapter 15 cover strategic planning and evaluation using NACC curricular guideline 16.0: Assessment, Evaluation and Decision-Making Methods.

The last chapter, Chapter 16, takes us beyond the NACC curricular guidelines, where Dyana P. Mason, Jennifer A. Jones, Lindsey McDougle and Cecilia Suarez provide a framework for critical pedagogies and argue that when instructors engage in more "critical" perspectives, students of nonprofit management will not only be able to consider questions of power and privilege within nonprofit organizations, but will also be able to understand the impact of power and privilege imbalances within the communities that they serve.

The majority of NACC guidelines are covered in this book, as well as future directions and considerations for teaching nonprofit management.

\section{REFERENCES}

Ahmed, S. (2005). Desired competencies and job duties of non-profit CEOs in relation to the current challenges: Through the lens of CEOs' job advertisements. Journal of Management Development, 24(10), 913-28.

Anheier, H. (2014). Nonprofit Organizations - Theory, Management, Policy, 2nd edn., Abingdon: Routledge.

Block, S.R. (1998). The role of Executive Director. In Jay M. Shafritz (ed.), The International Encyclopedia of Public Policy and Administration. Boulder, CO: Westview Press,.

Burlingame, D.F. (2009). Nonprofit and philanthropic studies education: The need to emphasize leadership and liberal arts. Journal of Public Affairs Education, 15(1), 59-67.

Carpenter, H.L. (2016). Preferences for a professional doctorate in philanthropy program. The Journal of Nonprofit Education and Leadership, 6(3), 224-42.

Dolan, D.A. (2002). Training needs of administrators in the nonprofit sector: What are they and how should we address them? Nonprofit Management and Leadership, 12(3), 277-92.

Fyall, R. (2017). Nonprofits as advocates and providers: A conceptual framework. Policy Studies Journal, 45, 121-43.

Jeavons, T.H. (1992). When the management is the message: Relating values to management practice in nonprofit organizations. Nonprofit Management \& Leadership, 2(4), 403-17. 
Kamaria, K. and Lewis, A. (2009). The not-for-profit general management responsive capability competencies: A strategic management perspective. Business Strategy Series, 10(5), 296-310.

Lewis, D. (2010). Nongovernmental organizations, definition and history. In International Encyclopedia of Civil Society (pp. 1056-63). New York: Springer.

Maier, F., Meyer, M. and Steinbereithner, M. (2016). Nonprofit organizations becoming business-like: A systematic review. Nonprofit and Voluntary Sector Quarterly, 45(1), 64-86.

McKeever, B. (2018). The nonprofit sector in brief 2018: Public charities, giving and volunteering. Urban Institute. Accessed 23 April 2019 at https://nccs.urban.org/ publication/nonprofit-sector-brief-2018\#the-nonprofit-sector-in-brief-2018-public -charites-giving-and-volunteering.

Mirabella, R. (2019). Nonprofit management education: Current offerings in university-based programs. Accessed 15 June 2019 at http://academic.shu.edu/npo/ list.php?sort=name.

Mirabella, R.M. and McDonald, M. (2013). University based programs in nonprofit management and philanthropic studies: Current state of the field and future directions. In Ronald J. Burke and Cary L. Cooper (eds), Human Resource Management in the Nonprofit Sector: Passion, Purpose and Professionalism. Cheltenham, UK and Northampton, MA, USA: Edward Elgar Publishing, 243-58.

Mirabella, R.M. and Wish, N.B. (2000). The "best place" debate: A comparison of graduate education programs for nonprofit managers. Public Administration Review, 60(3), 219-29.

Nonprofit Academic Centers Council (2015). Curricular Guidelines for Graduate Study in Philanthropy, the Nonprofit Sector and Nonprofit Leadership, 2nd edn., Cleveland, OH: NACC.

Salamon, L.M. and Sokolowski, S.W. (2005). Nonprofit organizations: New insights from QCEW data. Monthly Labor Review, 128, 19.

Smith, S.R. and Lipsky, M. (1993). Nonprofits for Hire: The Welfare State in the Age of Contracting. Cambridge, MA: Harvard University Press. 
Karabi C. Bezboruah and Heather L. Carpenter - 9781788118675 Downloaded from PubFactory at 04/26/2023 02:17:21PM 